\title{
New Directions
}

Volume 16 | Issue 4

Article 4

10-1-1989

\section{The Jeopardy of Private Institutions}

Alan Pifer

Follow this and additional works at: http://dh.howard.edu/newdirections

\section{Recommended Citation}

Pifer, Alan (1989) "The Jeopardy of Private Institutions," New Directions: Vol. 16: Iss. 4, Article 4.

Available at: http://dh.howard.edu/newdirections/vol16/iss4/4

This Article is brought to you for free and open access by Digital Howard @ Howard University. It has been accepted for inclusion in New Directions by an authorized administrator of Digital Howard @ Howard University. For more information, please contact lopez.matthews@howard.edu. 


\section{COMMENTARY}

\section{The Jeopardy of Private Institutions}

20

\section{Private nonprofit institutions serving}

the public good are one of those

special features of American lite so much taken for granted they have long since become obscured in a haze of familiarity. And yet, if one has occasion to observe life in a nation where all activities are functions either of the state or of a single, authorized political party, the value of independent private institutions, to our perception of a good society, becomes freshly and arrestingly apparent.

Traditionally, these institutions were supported almost exclusively by the income from endowments, annual gifts by individuals, corporations and foundations, and user fees; but as costs have risen and the demand for services has mounted, these sources of revenue have become increasingly inadequate. In recent years, therefore. many private institutions have begun to seek and receive a measure of governmental support, in the form of grants or contracts for specific purposes, or, indirectly, through subsidization of the purchaser of services, or, occasionally, at the local or state levels, as annual subventions.

A question that is more to the point is whether, in the aggregate, private institutions provide an essential element to the character of our national life. Would our society be as rich, as varied, as free, as lively, as it is, if these enterprises disappeared entirely from the scene - if all education took place in public institutions, if opera, ballet, drama, and music were performed only by official state companies, if medical care were provided only in public hospitals, if research were done only in governmental institutes, if welfare services were a monopoly of governmental agencies? Put this way, the question is rhetorical NEW DIRECTIONS OCIOBER 1999 citizens, through membership on boards of trustees and participation in a wide range of voluntary activities, to accept a significant measure of personal responsibility for the provision to the public of many kinds of essential services. Additionally, voluntary service by trustees and other supporters brings to these institutions special talents and experience they could not possibly command otherwise, in fields such as fund raising. legal affairs, investing. property management, and community relations. Growing recognition of the paramount importance of the last of these fields has stimulated many institutions to broaden membership in their governing boards to include more young people, more women, and more representatives of minority groups.

The second notable reason private service institutions and organizations must not be allowed to disappear is the important role they play in the safeguarding of academic, protessional. and artistic freedom in periods of sharp controversy, when legislative or executive pressure on public institutions becomes intolerable, private institutions can provide essential reserve protection for these freedoms. As one looks ahead, it is hard to imagine that the tensions of our deeply divided society will not produce many new storms, each with its own particular threats to liberty of mind and conscience. It has therefore seemed wise to many Americans to distribute the safekeeping of their nation's most precious asset, its intellectual freedom, among a variety of institutions under the control of private citizens as well as of public authorities.

A third, purely pragmatic, reason for securing the future well-being of these institutions is simply the fact that they do exist and that if they ceased to function as a private responsibility there is no guarantee that the same kinds and quality of service they now provide could or would be provided at public expense. This is particularly true in regard to some types of services provided by religious institutions, where the doctrine of separation of church and state bars public support: but it also applies to situations in which private institutions supply services of such a controversial nature
The first reason is the special opportunity they offer for concemed 
that public agencies would not dare to enter the field. The building of great institutions, be they universities. museums, symphony orchestras, hospitals, or independent research facilities, is a painstaking process, almost invariably requiring many decades Each successive generation of trustees, statt, and volunteers adds its increment to the facilities, the range of services provided, the professional standards, the espirit and the reputation of these institutions, until eventually they stand as mature resources to the society of a value incalculably greater than simply the worth of the "assets" which are listed in their annual balance sheets.

A fourth, and perhaps most important, reason private institutions must not be allowed to decline is that they bring to our national life vital elements of diversity, free choice, and heterodoxy. These qualities are often lumped together and their identity obscured in celebration of the vague and rather overworked concept of "pluralism." But each, in fact, has a quite different connotation, and each has its own special importance. Diversity suggests the existence of a variety of institutions within a given field. all rather different from one another in the way they are managed, in their perceptions of priorities, and in the kinds of service they offer. The term is value-free in that it contains no suggestion of superiority or inferiority. It says only that there are likely to be a number of ways to accomplish something and that in the long run the competition between several possible approaches is good for everybody. This prevents new ideas from being suppressed, it provides challenge to fat and complacent bureaucracies, it assures experimentation and flexibility, and it lends color to what might otherwise be a monochromatic scene.

Free choice applies to the consumer rather than to the purveyor of services. It implies the existence of a market, wherein those seeking services can shop around and take their trade where they choose. The market is, of course, not an entirely free one because the costs of private services are likely to be higher than those provided by public institutions. But the existence of the market is, all the same, important to the way the con- sumer feels about his life, for he knows that if a massive public agency whose services he was using were to become rigid, or inhumane, he would at least have the possibility of an alternative.

Heterodoxy describes the permit. ted presence in a society of unconventional ideas and philosophies and of institulions and organizations which nourish them. Tolerance of this kind is a sign of national maturity and selfconfidence and indicates faith in the good sense of the average citizen to sort out what is genuine and what [is] specious. It also recognizes that today's iconoclasm may, as the result of changing conditions, be tomorrow's orthodoxy and that any attempt forceably to stifle the free play of ideas, however seemingly eccentric, may produce stagnation or cause the buildup of powerful social forces that will eventually result in violent upheaval. Thus, the capacity to tolerate nonconformism, trying as this sometimes becomes, is the sine qua non of a free sociely. Without it the imposition of a totalitarian state ultimately becomes inevitable.

Private institutions are not the only contributors to pluralism. Public institutions can and do play a part in it: but their vulnerability in times of crisis places a special burden on private institutions for the preservation of diversity, of free choice, and of the capacity to tolerate heterodoxy - in short, for the preservation of an open society.

As service institutions, they have not been able to offset steadily rising labor costs through automation or other increases in productivity, or, alternatively, just to drop unprofitable services, as could a business enterprise. Either course would have constituted abandonment of their very raison d'etre-to provide services they deem to be good or essential for all or many citizens, and as much as possible on terms which the less fortunate can meet, At bottom, the problem faced by private institutions is very much the same as that faced by public institutions, except for the vital consideration that the latter's support is hitched to the tax dollars. Both have been hard hit by rising personnel costs. Both have found it impossible to offset these costs through in- creased productivity: More importantly, both have been seriously affected by an enormously heightened public demand, caused by affluence, population growth, changing attitudes, and related factors, for the kinds of educational, cultural, health, and welfare services which traditionally have been, and should be, supplied on a nonprofit basis.

Government, quite properly, has concentrated on the staggering problem of meeting this demand and in so doing has put the major part of its effort into the development of public institutions. This approach, understandable as it is, has been built on assumptions about the continued viability of private institutions as a national resource that have become less and less justified and consequently has precluded the kind of special attention they urgently require. Any real solution to the plight of private institutions must begin with a clear appreciation by the nation's top political leaders of what the collective presence and vitality of these institutions mean to the nation. These leaders, rather than simply mirroring public ignorance and apathy, must educate the public and where necessary, convert it, to a sense of active concern over the future of our traditional system of shared public and private effort and responsibility; and, in this task, our political leaders must be supported and reinforced by other leadership elements in the nation. Nothing less than this kind of impetus from the top will provide the basis for the great variety of measures which will be needed to preserve and revitalize the position of our private institutions. $\mathrm{D}$

Alan Pifer is now based at Southport Institute for Policy Analysis of which he is chairman. He is a/so chairman of the Consortium for the Advancement of Private Higher Education (CAPHE), a trustee of the University of Bridgeport, member of the advisory council of Heritage College in the state of Washington and a director of the Association of Governing Boards of Colleges and Universities. 